\title{
Otholobium outrampsii (Psoraleeae, Fabaceae) - a new species from the Western Cape, South Africa
}

\begin{abstract}
Authors
${ }^{1}$ Charles H. Stirton

1,2Brian du Preez (i)

\section{Affiliations \\ 'Bolus Herbarium, Department of Biological Sciences, University of Cape Town, Private Bag X3, Rondebosch, 7701, South Africa. \\ ${ }^{2}$ Department of Botany and Zoology, Stellenbosch University, Private Bag X1, Matieland, 7602, South Africa.}

\section{Corresponding Author}

Brian du Preez, e-mail: brian.enviro@gmail.com / bdp@sun.ac.za

\section{Dates}

Submitted: 27 July 2020 Accepted: 13 January 2021 Published: 10 August 2021

\section{How to cite this article:}

Stirton, C.H. \& Du Preez, B., 2021, 'Otholobium outrampsii (Psoroleeae, Fabaceae) - a new species from the Western Cape South Africa', Bothalia 51(2), a5. http://dx.doi.org/10.38201/btha. abc.v51.i2.5

Copyright: (C) 2021. The Authors. Licensee: SANBI. This work is licensed under the Creative Commons Attribution 4.0 International License.

\begin{abstract}
Otholobium outrampsii (Psoraleeae, Fabaceae) - a new species from the Western Cape Province, South Africa, is described and illustrated. This species is closely related to $O$. curtisiae but can be morphologically distinguished by it having semi-conduplicate, minutely glandular, softly pilose leaflets (versus flat, prominently glandular, glabrous leaflets); leaflet apex attenuate (versus leaflet apex shortly apiculate); calyx accrescent (versus calyx non-accrescent). The description of this new species further highlights the value of citizen science and by giving it the specific epithet 'outrampsii', we honour an incredible group of citizen scientists, namely the Outramps CREW group.
\end{abstract}

Keywords: Psoraleeae, Fabaceae, Otholobium, new species, taxonomy.

\section{Introduction}

Otholobium C.H.Stirt. (Fabaceae: Psoraleeae) is a genus endemic to southern Africa and most diverse in the Greater Cape Floristic Region (GCFR), where over 69 species are known to occur (Manning \& Goldblatt 2012; Stirton 1989). This paper describes a highly localised new species, Otholobium outrampsii, from the northern slopes of the Outeniqua Mountains in the Western Cape. It is a prostrate to semi-erect resprouting shrublet up to $20 \mathrm{~cm}$ tall with sparsely glandular, green hairy stems bearing semi-conduplicate, minutely glandular, softly pilose, narrowly elliptic to narrowly obovate leaflets with sparsely pilose margins. Inflorescences are terminal, pseudo-capitate and borne on short seasonal shoots and comprising 3-4 triplets of flowers. Fruiting calyces are accrescent.

\section{Materials and methods}

Permission to collect plant material in protected areas was provided by the Western Cape Nature Conservation Board (Permit: AAA 008-00222-0028). The morphological description was made based on herbarium specimens and fresh material collected in the field.

\section{Results}

1. Otholobium outrampsii C.H.Stirton \& B.du Preez sp. nov., closely allied to O. curtisiae C.H.Stirt. \& Muasya from which it differs in having green hairy stems with sparse, small, round, yellowish glands (versus purplish-green, hispid stems encrusted with prominent orange, urn-shaped pustules); semi-conduplicate, 
minutely glandular, pilose, narrowly elliptic to narrowly obovate leaflets, apex attenuate (versus flat, prominently glandular, glabrous, oblanceolate to oblong leaflets, apex apiculate); sessile pseudo-capitate 9-12-flowered terminal inflorescences borne on short seasonal shoots (versus capitate shortly pedunculate 3-6-flowered inflorescences borne in upper axils); flower triplets subtended by a flabellate bract (versus oblong bract); and accrescent calyx (versus non-accrescent calyx). TYPE: SOUTH AFRICA, Western Cape, lower northern slopes of Fouriesberg in Outeniqua Mountains, 3321DD,

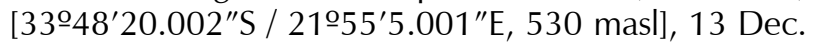
2013, Viviers \& Vlok 367 (holotype PRE!).

Prostrate to semi-erect shrublet $15-20 \mathrm{~cm}$ tall, resprouter. Stems 1 to many, branching along the prostrate stems, branches smooth, hairy when young, glabrous when older, flowering shoots clustered in the upper axils of the new season's growth, softly pilose, without urn-shaped pustules concentrated below leaves. Stipules 2.5-3.0 $\times 1.0 \mathrm{~mm}$, persistent, appressed to recurving, subulate, hairy. Leaves digitately trifoliolate, inserted spirally, semi-erect, shortly petiolate; petioles $1.0-1.5 \mathrm{~mm}$ long, petiolule $0.4-0.5 \mathrm{~mm}$ long, hairy; leaflets 8-10 × 2.0-2.4 mm, the later produced leaflets slightly smaller and more densely hairy, rigid, semiconduplicate, arching, narrowly elliptic to narrowly obovate, apex attenuate, base cuneate; terminal leaflet longer than laterals, symmetrical, laterals asymmetrical, glands sunken, scarcely visible with a $10 \times$ lens. Inflorescences pseudo-capitate in axils of short seasonal shoots, flowers in triplets, shorter than subtending leaves, comprising 3-4 triplets of flowers; each triplet subtended by a single $3 \times 12 \mathrm{~mm}$ long, flabellate, oblong, multiveined bract, narrowing towards the apex, caducous; peduncle absent. Flowers white, pedicel $2.8-3.0 \mathrm{~mm}$ long; each flower subtended by a narrowly lanceolate hairy bract up to $3.5 \mathrm{~mm}$ long. Calyx $5 \mathrm{~mm}$ long, accrescent; lobes subequal, vexillar teeth shortest, lanceolate, carinal tooth $2-3 \times$ wider, broadly lanceolate, dark green and strongly ribbed, with 3 prominent dark green veins, teeth sparsely glandular, densely white pilose along margins, hairs patent; tube $2 \mathrm{~mm}$ deep, pale green. Standard 6.5-7.2 × 5.5-6.0 mm, glabrous, broadly ovate, emarginate, white, nectar guide an arc of dark purple flecks near base of blade, appendages present on lower inner face, low, parallel and separate; claw short $\pm 0.5 \mathrm{~mm}$ long. Wing petals 5.5-6.0 $\times 1.8-2.2 \mathrm{~mm}$, blade broadly cultrate, white, scarcely auriculate, petal sculpturing present, upper basal and upper central comprising low parallel trans-costal ridges; claw $\pm 2 \mathrm{~mm}$ long, ribbon-like. Keel 4.2-4.5 $\times$ $1.5-1.6 \mathrm{~mm}$, white with a dark purple discolouration on almost half of inner face of blade; claw $\pm 2 \mathrm{~mm}$ long, ribbon-like; Androecium $\pm 3.8 \mathrm{~mm}$ long, vexillar stamen free and bent at base; anthers alternately basifixed and medi-fixed; small nectarial ring present. Pistil $\pm 3.5 \mathrm{~mm}$ long, glabrous, ovary $\pm 0.9 \mathrm{~mm}$ long, 1-ovulate, covered in a few recurved stalked glands; style ribbon-like, glabrous, entasis broadest before the point of flexure; stigma penicillate. Fruits and seeds unknown. Figures 1 and 2.

\section{Etymology}

The specific epithet outrampsii honours the members of the Outramps Group of the Custodians of Rare and Endangered Wildflowers (CREW) Programme, who have done much to champion the protection of the rare and threatened plants of the southern Cape, and who made a number of special trips to find flowering material of this rare species.

\section{Diagnostic characters}

Otholobium outrampsii is a post-fire resprouter and can be diagnosed by a combination of its prostrate to semierect spreading habit up to $20 \mathrm{~cm}$ tall, with scarcely pustulate, greyish hairy branches with persistent stipules, semi-conduplicate spreading minutely glandular, softly pilose, narrowly elliptic to narrowly obovate leaflets with an arching attenuate apex, asymmetrical lateral leaflets shorter than the terminal leaflet, leaflets glabrous except for sparsely softly pilose margins, glabrous when mature, and accrescent calyx with subequal lobes and large broadly lanceolate carinal lobe.

\section{Distribution and habitat}

Otholobium outrampsii is a rare and highly localised species known from the farm Paardebont, at the foot of Fouriesberg, west of the Robinson Pass on the northern side of the Outeniqua Mountains (Figure 3). This species occurs between the elevations of 430 and 550 $\mathrm{m}$ asl. The vegetation at this location is North Outeniqua Sandstone Fynbos (FFs18) as described by Mucina and Rutherford (2006). It favours dry, rocky and welldrained sandy soil derived from Table Mountain Sandstone in full sun on a southwest facing slope. Flowering only occurs after fire from late September to November.

\section{Conservation status}

Otholobium outrampsii is known only from a single location in the Outeniqua Mountains. The population size is estimated to be roughly 100 mature individuals. This species is threatened by the presence and spread of Hakea sericea Schrad. \& J.C.Wendl in and around the area from which this species is known. There is a potential threat from Acacia mearnsii De Wild. which is infesting the valley below. As the area is generally poorly explored and, given that the plants are small and inconspicuous when not in flower and only flower in the first year after fire, it is likely that other populations may be present on the surrounding hillslopes. 


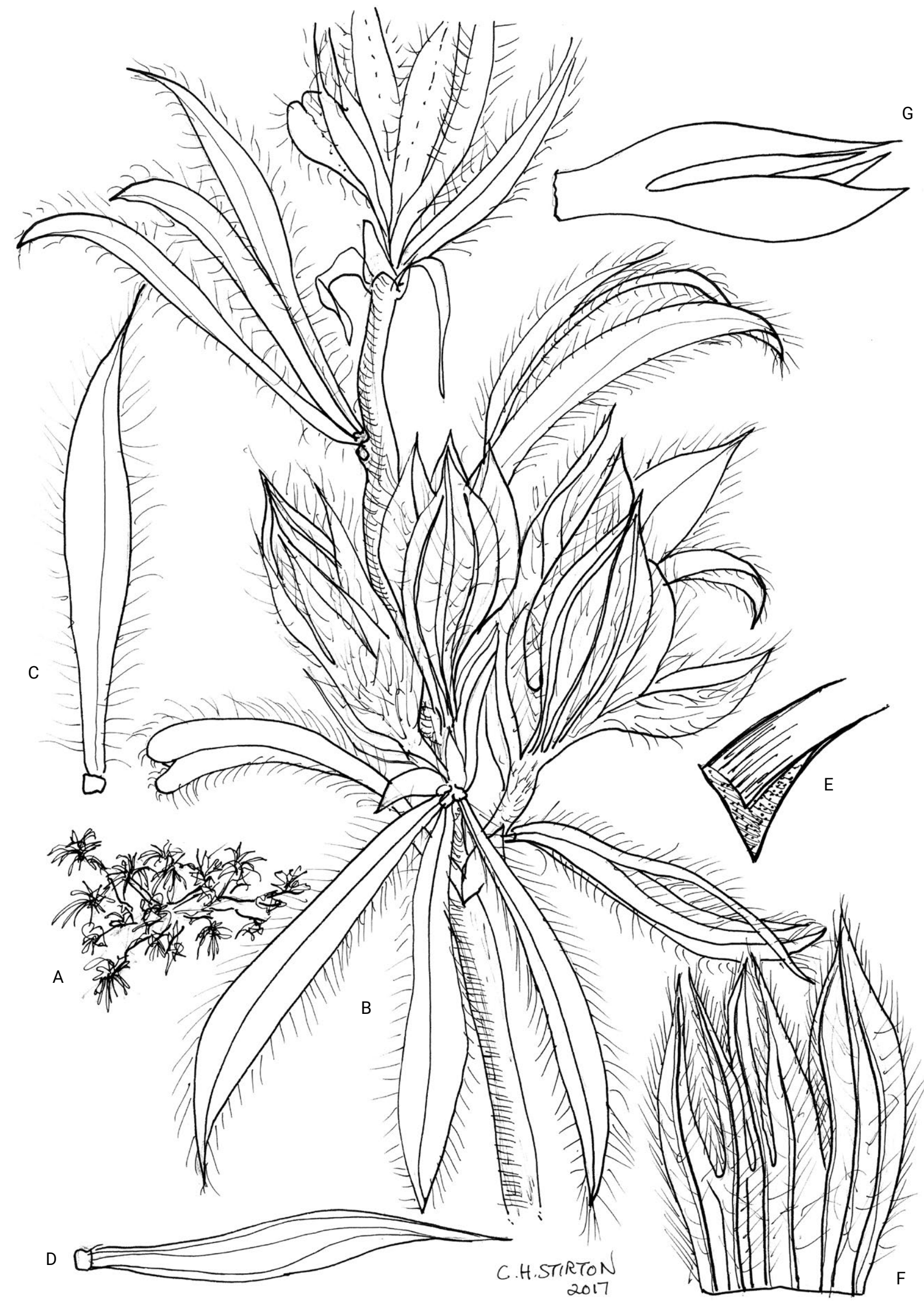

Figure 1. Otholobium outrampsii. A, habit of plant, $1 / 10^{\text {th }}$ life size; B, fruiting shoot showing accrescent calyces, $10 \times ; \mathrm{C}$, upper surface of terminal leaflet, $10 \times$; D, lower surface of old leaflet, $8 \times$; E, transverse section of leaflet, $20 \times$; F, calyx opened out, outer face, $7.5 \times$; $\mathrm{G}$, side view of calyx, $8 \times$. [Viviers \& Vlok 367 (PRE)]. Artist Charles Stirton. 

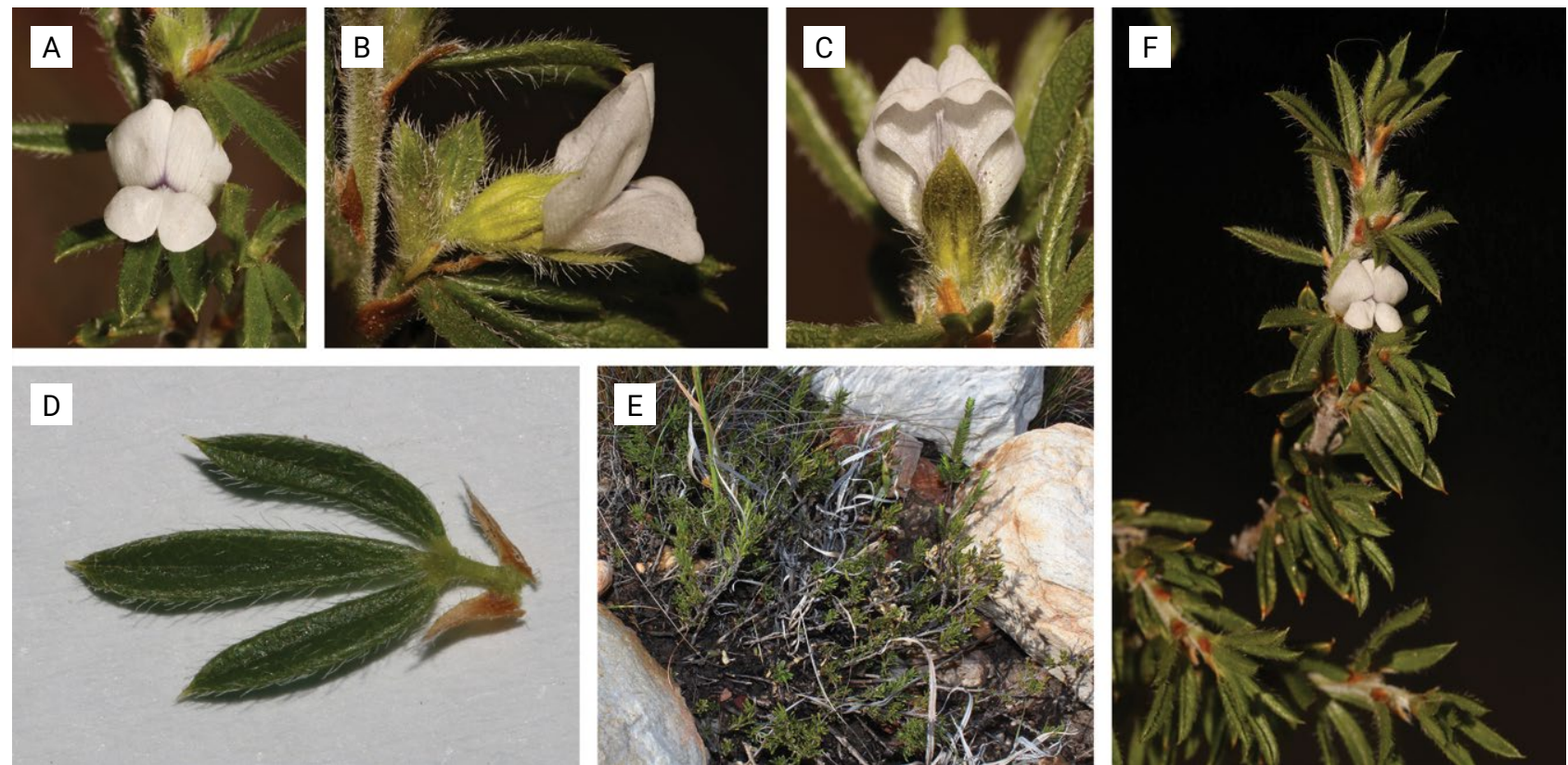

Figure 2. Otholobium outrampsii. A, flower front view; B, flower side view; C, flower ventral view; D, seasonal leaf adaxial surface; E, whole plant in habitat; F, flowering shoot. Photographs: B. du Preez.

Based on available data from surveys by members of the Outramps Group of CREW, a Red Data List status of Critically Endangered is recommended for O. outrampsii according to the IUCN categories and criteria (IUCN 2012).

\section{Additional specimens examined}

SOUTH AFRICA. Western Cape: $3 \mathrm{~km}$ south of Paardebont Farm, [33을'22.5"S / 21ㅇ5'6.527"E, 530 masl], 06 Nov. 2013, Outramps s.n. (BOL); Lower northern slopes of Fouriesberg in Outeniqua Mountains,

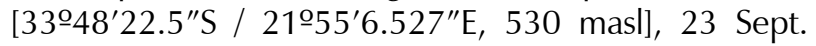
2019, B. du Preez 744 (BOL).

\section{Acknowledgements}

We wish to thank Jan Vlok and Mike Viviers, who first drew the first author's attention in 2013 to some sterile specimens they thought might be a new species. However, it was through the efforts of the Outramps CREW Group and the second author who eventually rediscovered the locality and collected flowering material that confirmed it as new. We wish to thank Abubakar Bello for helping in the making of our map figure. We also wish to thank Mr Cornel Fourie from the farm Paardebont for granting permission to access his property to visit the O. outrampsii population. We thank the two anonymous reviewers for their constructive comments.

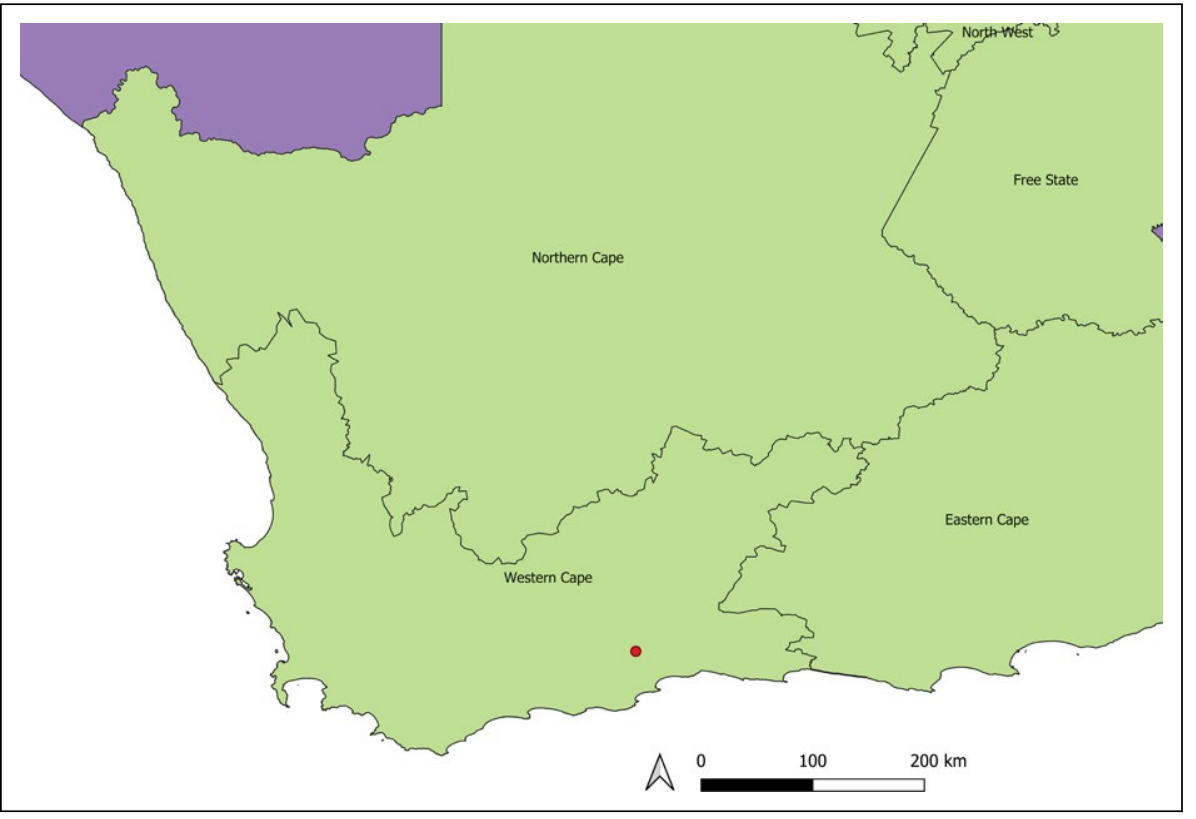

Figure 3. Known distribution of the endemic species Otholobium outrampsii in South Africa. 


\section{References}

IUCN (eds), 2012, IUCN Red List Categories and Criteria, Second edition, IUCN, Gland, Switzerland and Cambridge, UK.

Mucina, L. \& Rutherford, M.C. (eds), 2006, 'Vegetation map of South Africa, Lesotho and Swaziland', Strelitzia 19, South African National Biodiversity Institute, Pretoria.
Manning, J.C. \& Goldblatt, P. (eds), 2012, 'Plants of the Greater Cape Floristic Region. 1: the core Cape flora', Strelitzia 29, South African National Biodiversity Institute SANBI, Pretoria, pp. 853.

Stirton, C.H., 1989, A revision of Otholobium (Papilionoideae, Leguminosae), PhD Dissertation, University of Cape Town. 